\section{FONTOS AZ ADATELEMZÉS, DE MÉG FONTOSABB, HOGY TUDJUK-E AZ ADATOKAT HASZNOSIITANI INTERJÚ KRIZSÁN ERIKÁVAL}

Lambert Gábor (MABISZ) gabor.lambert@mabisz.hu

\section{ÖSSZEFOGLALÓ}

Krizsán Erika (Ügyvezetö Igazgató / Insurance Factory), közgazdasági egyetemet végzett, és többéves tapasztalattal rendelkezik hazai és nemzetközi biztosítótársaságok stratégiai, innovációs és szervezetfejlesztési projektjeiben. Tagja az ausztriai innovációs szakértői csoportnak. $\mathrm{Az}$ „Innovationsdruck in der Versicherungsbranche” című könyv szerzője.

Executive tanácsadó és üzleti tréner, fókuszálva az innovációs menedzsment témákra. Egyik kedvenc területe az üzleti trendkutatás, kiemelten: Hogyan néz ki a biztosítók jövője? Erre válaszol a mottója: „the best way to create your innovative insurance!”

\section{SUMMARY}

Erika Krizsán (Managing Director/Insurance Factory), graduated in Economic, having several years of experience in strategic innovation and organizational development projects of domestic and international insurance companies. Member of the Austrian expert group of innovation. Author of book "Innovationsdruck in der Versicherungsbranche". Executive consultant and business trainer, focusing on the topic of innovation management. One of her favourite disciplines is business trend searching, especially: What will the future of insurance industry look like? This question is responded by her motto: "the best way to create your innovative insurance!"

Kulcsszavak: biztosítás, innováció

Key words: insurance, innovation

\section{JEL: G22, O33}

\section{DOI: $10.18530 /$ BK.2018.4.6}

http://dx.doi.org/1018530/BK.2018.4.6
Az elmúlt években jelentős befektetés áramlott insurtech cégekbe. Két éve világszerte feleannyit fektettek be befektetők ezekbe a startupokba, mint amennyit az autóipar marketingre költött, 3 milliárd dollárt. Mire elég ez a töke?

A digitalizáció lehetősége új irányokat keres és talál felgyorsult világunkban, így került fókuszba a biztosítási iparág is. Azon befektetők és vállalkozások, akik már megismerték az e-kereskedelem világsikereit, és rácsodálkoztak a milliárdos nagyságrendű biztosítói üzleti modell nem éppen ügyfél- és adatcentrikus hiányosságaira, azt a célt tűzték ki, hogy új utakat építenek ezek megoldására. Mert tudják, ha olyan rendszereket építenek fel, amelyek adatelemzésekre, adatanalitikára képesek, akkor további marketingelőnyöket élveznek, jobb termékajánlatokat tudnak adni, és hosszú távon jövedelmezőbb üzleti modellt tudnak létrehozni. Ez az e-kereskedelemben nagyon jól működik, amit nagymértékben az Amazon professzionális adatvezérelt üzleti modelljének köszönhetünk. Az is jól látszódik, hogy jelenleg a biztosítói ágazat lemaradt ebben a fejlesztési versenyben. A hagyományokból eredően nagyon statikus rendszerek állnak rendelkezésre a szerződések feldolgozására, a károk kezelésére, a jutalékok számítására. Ezeknél a meglévő rendszereknél nehéz a megfelelő interface-eket felépíteni, és ez nagyon sok hibalehetőséggel, adatvesztéssel járhat. A biztosítási ágazat védelmére szólva, természetesen voltak fejlesztések (mert egyébként se a díjbeszedés, se a díjfizetési felszólítás, valamint sok-sok egyéb folyamat nem lenne megoldott), melyek inkább a folyamatok javítására, optimalizálására vagy törvényi kötelezettségek teljesítésére terjedtek ki, ezért a többi ágazathoz képest érzékelhető némi lemaradás. Így a befektetők által támogatott startupok elkezdték tesztelni az e-kereskedelem terén szerzett tapasztalatokat a biztosítási ágazatnál. Az első hullám az értékesítési folyamatot érte el. Az e-kereskedelem világában az ügyfél részleteiben ismeri a rendeléseit, azok értékét, mozgásait. Ezen minta szerint hoztak létre a biztosítók ügyfélportálokat, ahol meg lehet nézni, ki mennyi biztosítási díjat fizetett be, hol tart a unit-link befektetés értéke, figyelembe véve akár az összes biztosítási szerződés mozgásait.

A startupok sok-sok támogatási lehetőséget fejlesztettek ki. Kezdetben a fejlesztések inkább a meglévő folyamatok optimalizálására terjedtek ki. Például vannak olyan mesterséges intelligencia (MI) alapú megoldások, amelyek a meglévő alaprendszereket változtatás nélkül tovább működtetik, csak ezen alapokra fejlesztettek dinamikus „,roof”, illetve keretmegoldásokat. Ezen kisebb beruházások segítségével hatékonyabb értékesitéstámogatási rendszerek épültek ki.

Tehát az „ősrobbanás” az értékesítést forradalmasította. Milyen irányokban folytatódott-folytatódik a digitalizáció?

Még ma is nagyrészt az a helyzet, hogy az insurtech-ek elemzik a biztosítási értékláncot, azt, hogy hol tudnak jobb technológiai alapokra építve, jobb ügyfélélményt kitalálva, hatékonyabb folyamatokat támogatni. Az értékesítéstámogatási folyamatok modernizálását követően, a második hullámban a startupok az igazgatási vagy a kárrendezési folyamatot vették célba. Ha megnézzük a biztosítási költségstruktúrát, az értékesítés és az igazgatás terén látok hatalmas hatékonyságnövelési potenciált, illetve lehetőséget arra, hogy az új rendszereket ügyfélbarát módon fejlesszük. 
Utána következett a harmadik hullám, amely egy-két éve Európában is elindult: a biztosítók alapítanak digitális társaságokat, ahol mesterséges intelligencia alapokon „pay-as-you-drive/ live" biztosítókat fejlesztettek. Hosszú lista van már arról, hogy melyik biztosító melyik digitális társaságot alapította.

\section{Ennek a duplikálásnak mi az értelme?}

Egy hagyományos alapon müködő biztositónál nagyon nehéz egy-egy új ötletet megvalósítani teljesen digitális alapon. A rendszerek nem feltétlenül alkalmasak erre. Sokkal egyszerübb egy zöldmezős beruházással új digitális biztositótársaságot létrehozni.

\section{Tehát ma már a startupok nem annyira kihívói a szektornak, mint inkább kiszervezett} leányai?

Inkább azt mondanám, hogy is-is. Partnerek egyben új digitális megoldások kínálataival, másrészt konkurensek is, akik teljesen digitális megoldásokkal lépnek be a piacra. (1. ábra).

A negyedik hullám kialakítása is érezhető már, mely a kooperációs modellekre, platformokra épül: az ún. ökoszisztéma kialakítása a cél. Ennek az a lényege, hogy különböző ágazatok társaságai az ügyfélszemléletet előtérbe helyezve, egy-egy probléma megoldására keresnek közös, új üzleti modelleket. Ilyen ökoszisztémának tekinthetjük az okosotthon (smart home) világára felépülő modelleket. A mobilitás kérdése, az egészséges életmód támogatása, illetve a pénzügyi folyamatok lefedése mind olyan területek, ahová begyürüzhet a biztosítási igény.

Erre nagyon jó példa az egészség támogatására létrejövő közösségi platform, melyen keresztül ún. hordozható (wearable) technológiának köszönhetően az egészséges életmódra való ösztönzés kerül előtérbe, tippekkel, egészséges receptekkel. Itta biztositó mint személyes coach jelentkezik. Így, ha megfelelő aktivitást végzünk, kedvezőbb baleset-, élet- vagy egészségbiztosítást vásárolhatunk.

1. ábra: Insurtech tájkép

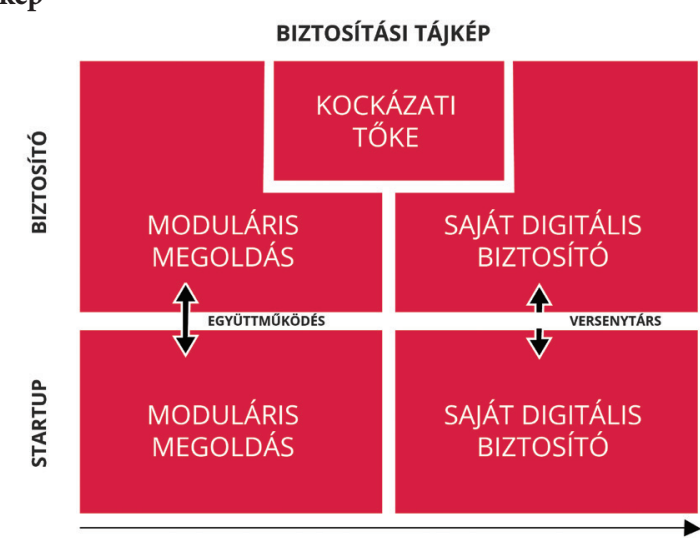

DIGITALIZÁCIÓ SZINTJE

Forrás: saját szerkesztés
Ez inkább Európára jellemző vagy Amerikára?

Amerikából természetesen sok-sok izgalmas digitális megoldás érkezik, mint például a Lemonade biztosító üzleti modellje, de az elmúlt időszakban az ázsiai fejlesztések is hatalmas erejüek. Ott már felismerték az ökoszisztémára alapuló üzleti működést, ott már a mesterséges intelligencia vagy a blockchain technológia a napi üzletmenet körébe tartozik. Ilyen például a Zhong-An biztosítója, a melynek jelenleg már több mint kétszáz partnercége van. Sikeresen alakították ki, hogy ebben az ökoszisztémában hol van a biztosító szerepe. Itt hatalmas befektetések vannak a háttérben, azt a célt szolgálva, hogy a jövő meghatározó szereplői legyenek, stratégiai partnerekkel megalapozva (a jelenlegi stratégia szerint nemzetközi terjeszkedési szándékkal).

Európában megfigyelhető, hogy a döntéshozók felismerték a digitalizáció lehetőségét, és különböző utak kiválasztásával próbálkoznak. A biztosítóknál is fellelhetőek az olyan kezdeményezések, mint az innovációs laboratóriumok kialakítása, az akcelerátor-programokban való részvétel, akár ötletversenyeket (hacketonokat), különböző inkubátorprogramokat is működtetnek. Az új utak keresésében nincs biztos recept. Hogy a hagyományos biztosítói modell megmarad-e, és hogy milyen formában, az a jövő nagy kérdése. Ami biztos, hogy az új generációk is szeretnék a különböző kockázatokat minimalizálni. Kérdés, hogy milyen megoldások születnek a biztosítók részéről ezen igények kielégítésére.

Az előbb említett Zhong-An például máris új termékekre, réspiacokra mozdul rá, egyedi ajánlatokkal. A hagyományos modell, a nagy kockázatközösségek építése helyett nem afelé megyünk máris inkább, hogy személyre szabott ajánlatokat próbál előállítani a szektor?

Én ezt inkább párhuzamos fejlődésnek látom, egyrészt természetesen a startupok ötleteit követve. Másrészt a hagyományos biztosítók is folyamatosan vezetnek be digitális megoldásokat. Sok-sok nemzetközi példát hoznak például a telematikai megoldások. A világ útjain már 14 millió autó közlekedik telematikai alapokon. Ennek a fontossága, illetve a szerepe Európában még nem mindenhol került előtérbe, különösen a német nyelvű területeken nem, ahol az adatvédelmi törvényekre hivatkozva inkább negatív lehetőségként szerepel. Ugyanakkor például Olaszországban (a legfejlettebb országok telematikai lehetőségeit kihasználva) a mérhetőség, a „pay as you drive” lehetősége, a lokalizáció szerepe a baleseteknél egyre inkább teret nyer.

Egy másik új réspiaci termékötlet a Zhong-An részéről, hogy ha például felmegy a külső vagy a testhőmérséklet 37 fok felé, akkor az nekem valamilyen kockázatot jelenthet, és arra biztosítást kötök. Vagy ha egy drága fényképezőgépet vásárolok, és elmegyek egy partira, legyen lehetőségem azt arra az időszakra biztosítani. Ezek kreatív ötletek, lehetőségek. Jelenleg számos olyan terület van, amelyet ma még nem fedünk le, de a digitalizáció új lehetőséget hoz létre ezen irányú termékfejlesztésekre. Ez nekem mint tradicionális, hatalmas ügyfélállománnyal rendelkező biztosítónak, az adatbázisomból kiindulva előnyt jelenthet egy új keresztértékesítési perspektívára. Az önműködő autók piacra lépésével az okozott 
balesetek száma jelentősen csökkenni fog, ezért a kockázatra kalkulált díjbevétel is jelentősen csökkenni fog. A kérdés az, hogyan fogom tudni pótolni ezt a díjbevétel-kiesést? Ma kell új üzleti modelleken törni a fejünket, hogy a működés fedezete hosszú távon biztosított legyen.

Közben azért a Zhong-An típusú biztosítók nem bátortalanítják el a befektetőket, hogy az iparágba befektessenek? Hiszen vannak ugyan ügyfelei sokmilliós nagyságrendben, ugyanakkor még mindig erősen veszteséges a vállalat. Hogyan csapódik le ez a hagyományos biztosítóknál? El mernek indulni hasonló irányokba, ha azt látják, hogy rendben van, mindez nagyon innovatív és kreatív, ám a végső és meghatározó mutató, a profit negatívba hajlik?

Ha megnézzük az e-kereskedelem világát, a sokat emlegetett Amazont, azt látjuk, hogy sokáig veszteséges volt az üzleti modell. De közben hatalmas ügyfélbázist épített fel, amelynek a mai értéke felbecsülhetetlen. Itt jelennek meg egy-egy vállalkozás életében a hosszú és rövid távú célok. A technológia fejlesztésére és a hozzá tartozó ügyfélállomány kiépítésére hatalmas befektetés szükséges. De ezek a beruházások a jövőt célozzák meg. A hagyományos biztosítók üzleti terveit ismerve, profitabilitás szempontjából ők is mintegy tízéves távlattal számoltak. (Még akkoriban is, amikor a befektetések kamatbevételei jóval jelentősebbek voltak.) Ugyanakkor hiszem, hogy a Zhong-An és társai mögött megalapozott üzleti tervek vannak lefektetve, csak más perspektívában, más célokat szolgálva. Például hosszú távú adatmennyiség felépítésére alapoznak. Egy másik érdekes példa Németországban a COYA digitális biztosítótársaság, ahol Peter Thiel (a PayPal alapítója) mint befektető jelent meg. Ô biztosan megalapozott üzleti modellt várt el az alapítóktól a több millió dolláros befektetéshez. Ha digitális biztosítóként zöldmezős beruházással indulok, nagyon nehéz azt az ügyfélbázist, amelyet a hagyományos biztosítók évtizedek alatt felépítettek, egyik napról a másikra megszerezni. Ugyanakkor a digitális technológiával ezen ügyfelek megszerzésére fordított összeg jelentősen kevesebb, mint a hagyományos értékesítési technológiára alapozva. Egy egy-két dolláros biztosítás értékesítése tíz év múlva akár száz dollárt is hozhat, ha gondosan fel van építve az ügyfélhűség kialakítása.

Közép-Európa hol áll ebben a folyamatban?

Ha Ausztriát - ahol több mint 15 éve élek - vesszük figyelembe, ott még mindig nagyon erős a személyes értékesítés varázsa. Semmilyen online értékesítési megoldásra még nincs jelentős igény. Az összehasonlító portáloknak köszönhetően javult ugyan a helyzet, de még nem jelentős az online kötések száma. Magyarországon már sokkal jobb a helyzet, mert például a kötelező biztosítások túlnyomó többségét már online kötik. Ausztriában ez az arány még öt százalék alatt van. A kárrendezésnél az az általános folyamat Ausztriában, hogy felhívom a brókeremet vagy a tanácsadómat, ha károm van, és biztos lehetek benne, hogy a teljes ügyintézést „a nyakába veszi” az ügyfél helyett. Ausztria megítélésem szerint az ügyféligény tekintetében az európai hátsó mezőnybe tartozik, mert a digitalizáció igényei egyfelől az ügyfelek részéről sincsenek meg, másrészt jelen esetben túl sok ajánlat sincsen a biztosítók részéről. De természetesen az újonnan létrejött digitális biztosítókat már papírmentesen és ügyfélszempontból, az ügyfélélmény biztosítása érdekében építik fel.

A biztosítás mely területei számítanak a digitalizáció szempontjából a leginkább ígéreteseknek?

Az első lépések az autóbiztosítás, illetve az utasbiztosítás terén már megtörténtek. A következő aktivitások a lakás-, baleset- és életbiztosítások területére terjednek ki. Illetve egy réspiaci vonulat is érezhető a kerékpárok, állatok, technikai eszközök (telefon, tablet, számítógép) vonatkozásában. Egy újabb trend már az „ökoszisztémára” felépített rendszereken belül jelenik meg, ilyen például a kiberbiztosítások értékesítése, ami például telefonszolgáltatókkal kooperálva történik.

Egy szakmai konferencián azt a kérdést tették fel a jelenlevőknek, hogy egy hotel vagy egy Airbnb törölközőire kínálnának-e inkább biztosítási fedezetet? Az Airbnb nyert, abból kiindulva, hogy a negatív kommentektől való félelem miatt nagyobb biztonságban vannak a kiadott lakás törölközői, mint a szállodáé. A közösségi gazdaságban bevált reputációs kockázati hatás müködhet a biztosításokban is?

Különösen az új generációk tekintetében egy megatrend a közösségi gazdaságban (shared economy-ban), azok körében, akik már nem tulajdonolni akarnak, hanem megosztani. Pár éve a biztosítóknál is megjelent a tendencia, hogy „peer to peer” irányba próbálkoznak közösségi biztosítást kialakítani. Vagyis csoportokat képeznek, és a kis károkat a csoportba befizetett díjakból fedezik. Érdekes modell az ügyfelek számára, hogy ha nincs káresemény, visszakapják díjuk egy részét. Ám a biztosító szempontjából rövid távon ez nem feltétlenül nyereséges, úgy gondolom, hogy legalább öt-tízmilliós ügyfélszámnál és hosszabb időszak alatt fordulhat csak át a mérleg nyelve pozitív irányba.

Mennyire hatott az egész ágazatra a Lemonade modell, vagyis az, hogy meghatározott összegig vita nélkül és gyorsan fizetik a kárbejelentéseket?

A digitális biztosítóktól folyamatosan tanulnak a hagyományos biztosítók, mert kezdik kialakítani az ügyfélélmény-alapú folyamatokat, rendszereket.

A biztosítók pozitív imázsának a növelése érdekében szerintem lehetőség az ügyfélbefizetéseken át a kárkifizetésig a transzparencia és az egyszerüsítés kérdésének az előtérbe helyezése, amihez a mai technológiai lehetőségek már nagymértékben hozzájárulnak. Így a digitális biztosítóktól folyamatosan tanulnak a hagyományos biztosítók, mert kezdik kialakítani az ügyfélélmény-alapú folyamatokat, rendszereket.

Ha a jelenlegi generációk talán még nem is annyira igénylik ezeket a folyamatokat, de az új nemzedékek már magukkal hozzák ezeket az igényeket. 
Miközben egyre nagyobb hangsúly terelődik a személyes adatgyüjtésre, a big data korszaka változtat-e azon a logikán, hogy a biztosítás utólagos kárenyhítést jelent? Nem a preventív megoldásokra terelödik egyre inkább a hangsúly? Amikor azt díjazom, hogy az ügyfél megad magáról minél több adatot, és ki tudjuk szürni a kockázatokat?

Ez a perspektíva az utóbbi időben érződik, mint ahogy a telematika kapcsán már említettem is. Vagy akár már az életbiztosítások terén is, ahol a hordozható okoseszközök segítségével lehetősége van a biztosítónak arra, hogy az adatokat elemezve az egészséges életmóddal kapcsolatos további ügyfél-motivációt teremtsen meg.

Az okosotthonok kiépítése kapcsán lehetőség van például energia megtakarítására, ahol esetleg a szenzor technológia segítségével elemzem a vízvezetékek állapotát. A szenzorokkal, adatokkal kiépített prevenció minden területre begyürüzik. A biztosításokban azonban még nincs meg olyan minőségben az az adatmennyiség, mint az e-kereskedelemben, másrészt pedig a biztosítóknak még tanulniuk kell, hogy mire tudják használni az „új olajat”, az ügyféladatokat.

\section{Hogyan hat erre a tanulási folyamatra a GDPR? Lehet már érezni a hatását?}

Európában valóban teljesen más a törvényi háttér, mint Kínában vagy Amerikában. Kínában a nyílt utcán például, ha elmegyek egy állami épület elött, az arcfelismerésnek és a mesterséges intelligenciának köszönhetően már tudják is, hogy ki vagyok. Tehát az adatelemzés eléggé tág teret kap. Európában jelenleg a média segítségével nem az előnyök, inkább a hátrányok, a negatívumok kerülnek elötérbe. Nem az kap hangsúlyt, hogy ha a telematika segítségével megadom az autóm helyzetét, akkor egy balesetnél sokkal gyorsabban tud a segítség megérkezni. Olaszországban például, ahol a telematika szerepe sokkal pozitívabban van beállítva, az ügyfelek már mint szolgáltatásért fizetnek is érte. Európa más országaiban viszont inkább negatívan ábrázolják az adatgyüjtési és adatelemzési tematikát.

Nem éppen azért, mert látható, hogy Kínában hová vezetett az adatgyüjtés?

Ha azt látom, hogy én mint ügyfél, valamilyen előnyt tudok kovácsolni abból, hogy az adataimat megadom, akkor meg fogom adni. De ma még nagyon negatív felhangok kísérik, amikor egy-egy biztosító mondjuk életvezetési tanácsokat adva, a begyüjtött adatok után pontozva díjkedvezményeket biztosít az ügyfeleinek. Pedig ez a hozzáállás Kínával és Amerikával szemben hamarosan versenyhátrányt jelenthet. Természetesen az adatvédelem fontos dolog, de nem abszolút, mindenek felett álló

A biztosítóknak jutalmazási perspektívájuk van, nem díjnövelési szándékuk. Az adat- és ügyfélgyüjtési szemlélet sokkal fontosabb hosszú távon.

És mi garantálja, hogy nem érkezünk el egy olyan állapothoz, amikor a big data már csak az ügyfelek kimazsolázásában segít, és a rosszabb helyzetben lévőkkel vagy csak sokkal drágábban, vagy egyáltalán nem kötnek biztosítást, az államra hagyva, hogyan oldja meg ezt a problémát? Végleg eltemetve ezzel a nagy kockázatközösségen belüli szétporlasztás hagyományos logikáját?
Egy bizonyos, a szelektálás ma isjelen van, amikor a kockázatelbíráló manuálisan dönti el, hogy mely kockázatot vállalja be, illetve melyiket nem, mivel a profitorientált biztosítók mindenkori célja, hogy alacsony rizikójú ügyfélbázist építsenek fel. Ez kétségtelenül nagyon összetett kérdés, de a szelektálás már ma is működik, a technológiai lehetőségek csak finomíthatnak a döntéseken.

Ugyanakkor az is lehet, hogy az adatelemzés arra késztet, hogy egészségesebben éljek. Pozitív megközelítésben ennek számos előnye lehet az ügyfelek és a biztosítók szempontjából is. Ma még az adatgyüjtés és -feldolgozás rendszere nem olyan magas színvonalú.

Az, hogy a mesterséges intelligencia, az MI egyre olcsóbbá és hozzáférhetőbbé válik, veszély vagy lehetőség az iparág számára?

Én a technológiát, azt, hogy hogyan tudom hatékonyabbá, költségkímélőbbé, akár ügyfélélmény szempontjából érdekesebbé tenni a biztositói ágazatot, mindenképpen lehetőségnek tekintem. A mesterséges intelligencia, mely az egyik legjelentősebb fejlesztés volt és lesz, a jövőben további exponenciális fejlődésnek néz elébe. Az egyik jelentős lehetőség a kárrendezési folyamatok hatékonyabbá tételében van. Például lefényképezek egy káreseményt, majd az MI segítségével elemzem a kár nagyságát, és rövid időn belül megkapom a kárkifizetésre vonatkozó ajánlatot. Az ügyfél pedig eldönti, hogy elfogadja azt, vagy sem. Ha igen, akkor pár percen belül a számlán van a kárösszeg - és máris megjelent a hatékonyság mellett az „ügyfélélmény” is.

A mesterséges intelligencia és a blockchain technológia az egész üzletági gondolkodásmódot befolyásolhatja. Ezeknek a lehetőségeknek a kiaknázásában még nagyon az elején járunk. A technológia begyürüzik a mindennapjainkba, folyamatosan fejlődik, ugyanakkor még tanulni kell, hogy milyen lehetőségeket teremt akár további üzletszerzésre, vagy hogyan tudjuk kihasználni a gépi mélytanulás, a „deep learning” lehetőségeket, amikor a rendszerek már saját maguk is ötleteket adnak a továbbfejlesztésre.

A szaksajtó szerint a német insurtech-ekbe áramló tőke, és így ezen cégek finanszírozása nem olyan erős, mint az angolszász országokban. Mi ennek az oka?

Részben az, hogy különböző érdekek jelennek meg a digitalizáció elörevitelében. Egyrészt a támogatók, másrészt az ellenzők. Mivel a mesterséges intelligencia kiépítése olyan folyamatokhoz vezethet, hogy bizonyos munkákat - és ma már nem csak fizikai munkákat - kiváltanak a robotok, ez középtávon munkahelyvesztést okozhat. A vezetökre így döntési nyomás helyeződik, hogy milyen irányba tereljék a cégek stratégiáját. Az angolszász országokban, különösen, ha Amerikát nézzük, az „entrepreneur spirit”, a vállalkozószellem mindig sokkal erősebb volt, mint Közép-Európában, ahol inkább a félelem van jelen a jövő technológiáit figyelembe véve. Úgy gondolom, hogy Európában még „gyerekcipőben” jár a digitalizációs stratégia kidolgozása, mind kormányzati, mind európai szinten. Ugyanakkor a technológiai fejlődést nem lehet megállítani. A kérdés, hogy a szörfdeszkánkkal rajta tudunk-e maradni a hullámokon, vagy csak szemlélői, esetleg elszenvedői és nem aktív szereplöi leszünk a digitális változásoknak. 